\title{
DESTAQUE EDITORIAL
}

\section{A PÓS-GRADUAÇÃO NO BRASIL: FORMAÇÃO E TRABALHO DE MESTRES E DOUTORES NO PAÍS}

Jacques Velloso (coord.)

Brasília: Coordenação de Aperfeiçoamento de Pessoal de Nível Superior, 2003, v.2, 290p.

A pós-graduação no Brasil adquiriu grande importância no sistema de ensino superior brasileiro, tendo passado por notável crescimento nos anos 90. Para obter um conhecimento mais acurado acerca das relações entre a formação recebida nesse nível e o destino profissional de mestres e doutores formados no país, a Coordenação de Aperfeiçoamento de Pessoal de Nível Superior - Capes -, com o apoio da Organização das Nações Unidas para a Educação, a Ciência e a Cultura - Unesco -, patrocinou ampla pesquisa, visando fornecer subsídios ao aperfeiçoamento dos cursos pós-graduados e às políticas do setor.

O propósito do estudo foi o de oferecer respostas a questões como: Quem são os mestres e doutores titulados no país? $\bigcirc$ que faziam antes e o que passaram a fazer após a titulação? Que contribuições os cursos aportaram ao seu desempenho profissional?

Jacques Velloso coordenou a pesquisa, articulando em torno do Núcleo de Estudos sobre o Ensino Superior da Universidade de Brasília vários grupos similares, sediados nas universidades federais da Bahia, de Minas Gerais, Pernambuco, do Rio Grande do Sul, Rio de Janeiro e na Universidade de São Paulo. A investigação abrangeu nada menos do que 15 áreas do conhecimento e envolveu entrevistas com aproximadamente nove mil mestres e doutores titulados na década de 1990; delineia, portanto, um retrato bastante representativo do cenário nacional.

As duas primeiras etapas da pesquisa deram origem ao primeiro volume da publicação, que diz respeito aos egressos dos cursos de $\mathrm{Ad}$ ministração, Agronomia, Bioquímica, Clínica Médica, Engenharia Civil, Engenharia Elétrica, Física, Química e Sociologia. Este segundo volume refere-se às áreas de Direito, Economia, Engenharia Mecânica, Geociências, Odontologia e Psicologia e trabalha com dados provenientes de cerca de 3,5 mil egressos da pós-graduação.

A despeito da especificidade das áreas, o estudo chega a algumas conclusões abrangentes. Uma delas é a de que o período transcorrido entre o término da graduação e a aquisição do título de doutor é muito longo no Brasil. Gira em torno de I I anos, enquanto nas nações centrais, independentemente da área considerada, o doutorado é obtido em um intervalo mais curto de tempo.

Outra conclusão que merece destaque é que a formação recebida na pós-graduação parece preencher bem as expectativas e demandas das profissões acadêmicas; contudo, afasta-se mais e torna-se menos relevante no caso das ocupações voltadas a outros campos de trabalho.

Espera-se que a discussão suscitada pelos dados e reflexões trazidos à luz nesta pesquisa que, sem dúvida, constitui o estudo de mais largo fôlego realizado sobre a pós-graduação no país -, possa apontar novas perspectivas para os seus cursos, particularmente no que se refere ao atendimento às demandas decorrentes das transformações tecnológicas contemporâneas. 